\title{
MyPlate Foods to Increase: Fruits and Vegetables ${ }^{1}$
}

\author{
Jonathan Holzinger, Karla Shelnutt, and Gail Kauwell ${ }^{2}$
}

The U.S. Department of Agriculture (USDA) recently released a new symbol to promote healthy eating called MyPlate. MyPlate represents the most recent recommendations in the Dietary Guidelines for Americans, 2010. The new symbol (Figure 1) uses a plate to teach consumers how much of each food from the food groups they should eat. The food groups on the plate include Fruits, Vegetables, Grains, and Protein Foods, and a cup on the side represents foods from the Dairy group.

The USDA has also developed key messages to go along with the MyPlate symbol. Following these messages can help consumers make more nutritious food choices. The key message related to fruits and vegetables is to "Make half your plate fruits and vegetables." This publication provides information on fruits and vegetables and includes tips on how to add more of them to your diet.

\section{What Foods Are in the Fruits Group?}

All fruits and $100 \%$ fruit juices are included in the Fruits group, and these can be fresh, canned, frozen, or dried (USDA, 2012). When buying fruits, make sure there is not any added sugar in canned or frozen fruits. The fruits you choose can be whole, cut into pieces, or pureed. A variety of tasty fruits such as melons, berries, citrus, and tropical fruits are all included in the Fruits group. Have you ever tried a carambola (star fruit)? What about a mango or papaya? Be adventurous and try a new fruit today!

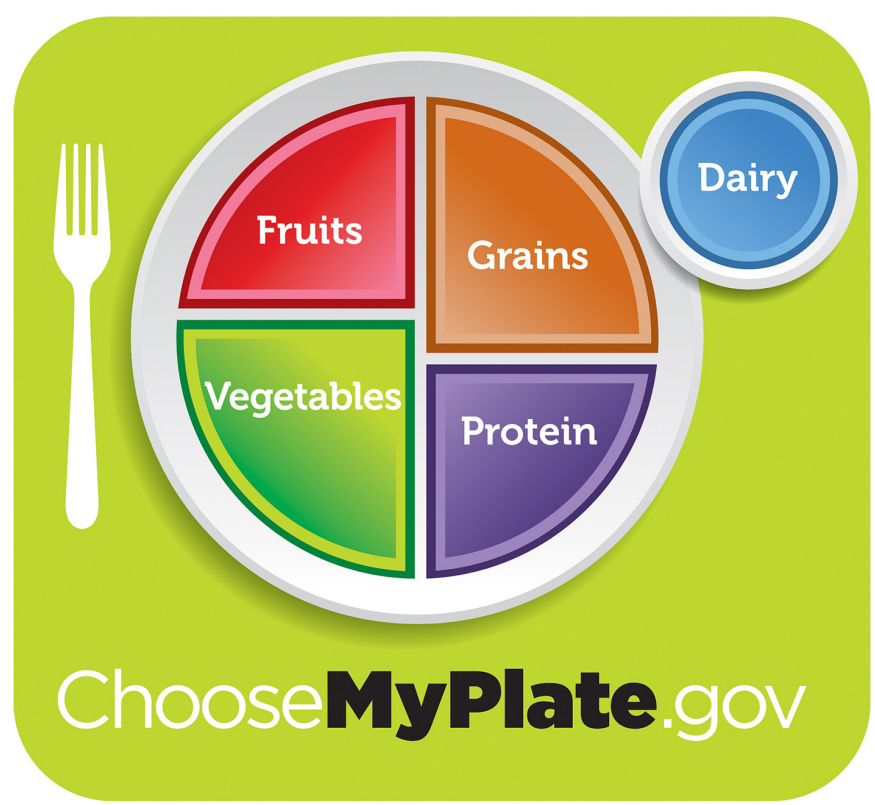

Figure 1. USDA's MyPlate symbol provides an easy guide for people to know how much of each type of food to include in their diets (USDA, 2012). Credits: http://www.choosemyplate.gov

\section{Daily Recommendations for Fruit}

The amount of fruit you need every day depends on your age, sex, and daily physical activity. Table 1 summarizes daily fruit recommendations for people who exercise less than 30 minutes every day. If you are more active, you may need to eat more to meet your calorie goal (USDA, 2011a).

1. This document is FCS80022, one of a series of the Department of Family, Youth and Community Sciences, Florida Cooperative Extension Service, Institute of Food and Agricultural Sciences, University of Florida. Original publication date February 2013. Please visit the EDIS website at http://edis. ifas.ufl.edu.

2. Jonathan Holzinger, dietetic intern, Food Science and Human Nutrition Department; Karla Shelnutt, PhD, RD, assistant professor, Department of Family, Youth, and Community Sciences; and Gail Kauwell, PhD, RD, LD/N, professor, Food Science and Human Nutrition Department; Florida Cooperative Extension Service, Institute of Food and Agricultural Sciences, University of Florida, Gainesville, FL 32611. 


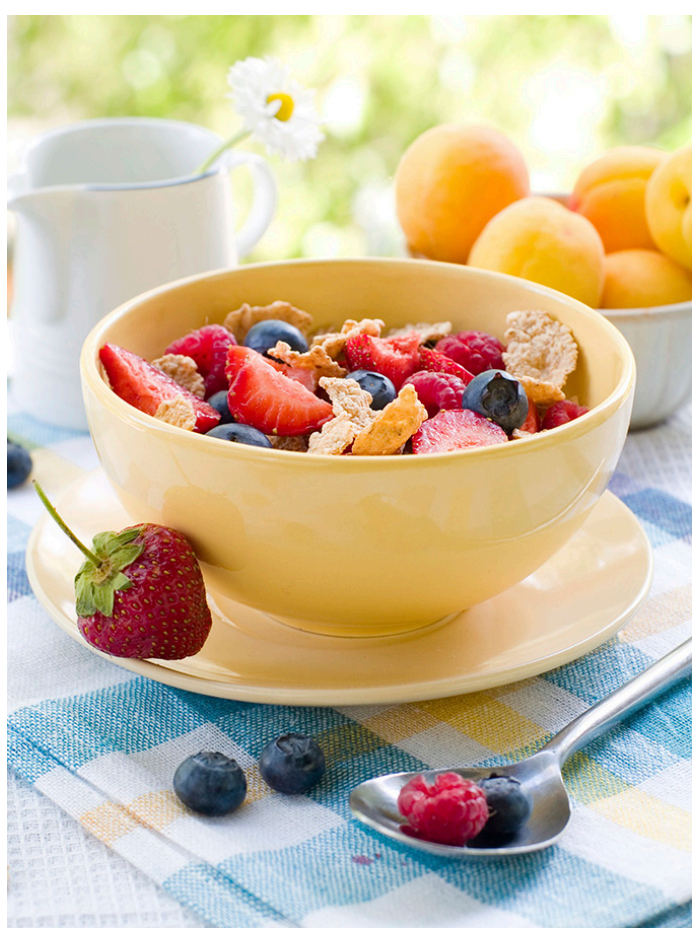

Figure 2. Adding fruit to your morning cereal is a good way to increase the amount of fruit in your diet. Credits: iStockphoto

Table 1.

\begin{tabular}{|l|l|l|}
\hline \multicolumn{3}{|c|}{ Daily Recommendations for Fruit } \\
\hline Children & $\begin{array}{l}2-3 \text { years old } \\
4-8 \text { years old }\end{array}$ & $\begin{array}{l}1 \text { cup } \\
1-11 / 2 \text { cups }\end{array}$ \\
\hline Girls & $9-18$ years old & $11 \frac{1}{2}$ cups \\
\hline Boys & $\begin{array}{l}9-13 \text { years old } \\
14-18 \text { years old }\end{array}$ & $\begin{array}{l}11 / 2 \text { cups } \\
2 \text { cups }\end{array}$ \\
\hline Women & $\begin{array}{l}19-30 \text { years old } \\
31+\text { years old }\end{array}$ & $\begin{array}{l}2 \text { cups } \\
11 / 2 \text { cups }\end{array}$ \\
\hline Men & $19+$ years old & 2 cups \\
\hline Source: USDA, 2011a & & \\
\hline
\end{tabular}

\section{What Foods Are in the Vegetables Group?}

The Vegetables group includes all vegetables and $100 \%$ vegetable juices. You can eat your vegetables raw or cook them with your favorite dish. Make sure to buy fresh vegetables when they are in season to save money. You do not have to buy fresh vegetables all of the time. Canned and frozen vegetables provide the same nutrients and can be cheaper options if you are sticking to a budget. Limit products with added salt to help keep your sodium intake low.

The vegetables you choose can be whole, cut into pieces, or mashed. Have you ever tried mashed cauliflower instead of mashed potatoes? Try it! Your family may not even notice a difference, and it may be a great way to get them to try a new vegetable.

The Vegetables group has five different subgroups. These subgroups include dark green, starchy, red and orange, beans and peas, and other vegetables. Eat a variety of vegetables from the different subgroups because they all provide different nutrients. Examples of vegetables from each of the subgroups are listed in Table 2.

Table 2.

\begin{tabular}{|l|l|}
\hline Dark Green & $\begin{array}{l}\text { Broccoli } \\
\text { Spinach } \\
\text { Collard Greens }\end{array}$ \\
\hline Starchy & $\begin{array}{l}\text { Corn } \\
\text { Potatoes } \\
\text { Green peas } \\
\text { Lima beans }\end{array}$ \\
\hline Red and Orange & $\begin{array}{l}\text { Carrots } \\
\text { Pumpkin } \\
\text { Tomatoes }\end{array}$ \\
\hline Beans and Peas & $\begin{array}{l}\text { Black beans } \\
\text { Kidney beans } \\
\text { Soy beans }\end{array}$ \\
\hline Other & $\begin{array}{l}\text { Asparagus } \\
\text { Cucumbers } \\
\text { Mushrooms }\end{array}$ \\
\hline
\end{tabular}

\section{Daily Recommendations for Vegetables}

Like fruits, the amount of vegetables you need every day depends on your age, sex, and level of activity. Table 3 contains a summary of the recommended daily amount of vegetables for people who exercise less than 30 minutes every day. If you are more active, you may be able to eat more to meet your calorie goal (USDA, 2011b).

Table 3.

\begin{tabular}{|c|c|c|}
\hline \multicolumn{3}{|c|}{ Daily Recommendations for Vegetables } \\
\hline Children & $\begin{array}{l}2-3 \text { years old } \\
4-8 \text { years old }\end{array}$ & $\begin{array}{l}1 \text { cup } \\
11 / 2 \text { cups }\end{array}$ \\
\hline Girls & $\begin{array}{l}9-13 \text { years old } \\
14-18 \text { years old }\end{array}$ & $\begin{array}{l}2 \text { cups } \\
2 \frac{1}{2} \text { cups }\end{array}$ \\
\hline Boys & $\begin{array}{l}9-13 \text { years old } \\
14-18 \text { years old }\end{array}$ & $\begin{array}{l}21 / 2 \text { cups } \\
3 \text { cups }\end{array}$ \\
\hline Women & $\begin{array}{l}19-50 \text { years old } \\
51+\text { years old }\end{array}$ & $\begin{array}{l}21 / 2 \text { cups } \\
2 \text { cups }\end{array}$ \\
\hline Men & $\begin{array}{l}19-50 \text { years old } \\
51+\text { years old }\end{array}$ & $\begin{array}{l}3 \text { cups } \\
21 / 2 \text { cups }\end{array}$ \\
\hline \multicolumn{3}{|c|}{ Source: USDA, $2011 \mathrm{~b}$} \\
\hline
\end{tabular}




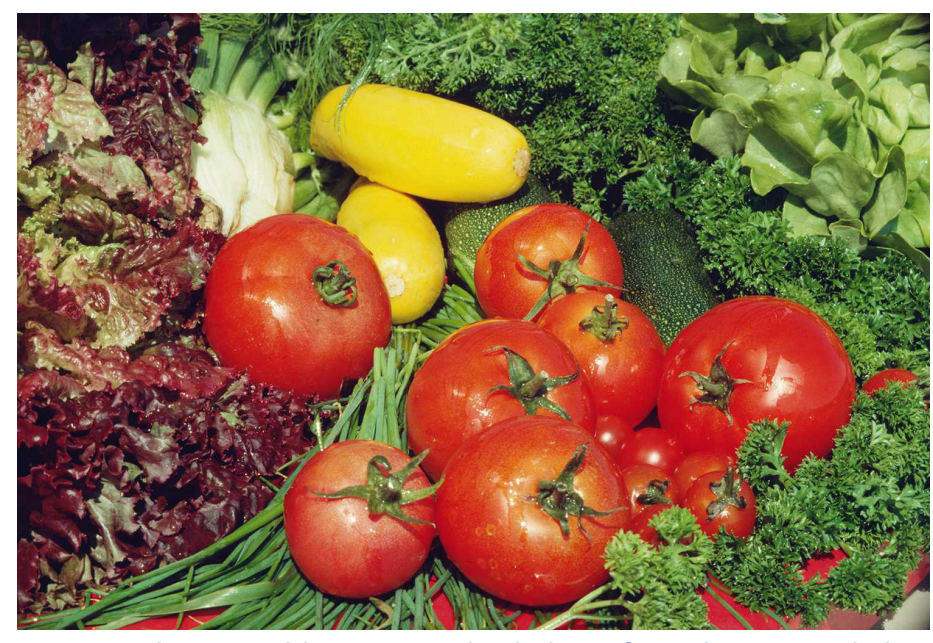

Figure 3. The Vegetables group is divided into five subgroups - dark green (e.g., broccoli, spinach), starchy (e.g., corn, potatoes), red and orange (e.g., tomatoes, carrots), beans and peas (e.g., black beans, kidney beans), and other (e.g., cucumbers, asparagus). Make sure to eat vegetables from all of these groups to get different nutrients. Credits: Photos.com @Getty Images

\section{Why Are Fruits and Vegetables Important?}

Fruits and vegetables provide several nutrients that Americans may lack in their diets. These include magnesium, potassium, vitamins A, C, and K, and dietary fiber. Eating fruits and vegetables is associated with a reduced risk for chronic diseases like heart disease. Fruits and vegetables are also relatively low in calories, which is important for people trying to achieve or maintain a healthy weight.

When eaten as part of a healthy diet, some fruits and vegetables may even protect against certain types of cancer (USDA and U.S. Department of Health and Human Services, 2010). Eating fruits and vegetables is associated with a reduced risk for certain chronic diseases because they contain dietary fiber and phytochemicals. Dietary fiber helps lower cholesterol, and people who get the recommended fiber intake (approximately 38 grams/day for men and 25 grams/day for women) have a lower risk for developing heart disease, stroke, high blood pressure, and diabetes (Anderson et al., 2009). Phytochemicals are compounds in fruits and vegetables that help protect the body from free radical damage (Liu, 2003).

Eating five servings of fruits and vegetables every day ( 80 grams per serving) has also been shown to help lower blood pressure in healthy adults with high blood pressure. One study showed that fruit and vegetable intake (five servings per day over six months) resulted in lower blood pressure (John, Ziebland, Yudkin, Roe, \& Neil, 2002). The authors concluded that the improved blood pressure readings resulted from an increase in potassium intake from fruits and vegetables and possibly a lower intake of sodium. Some fruits and vegetables that are good sources of potassium (containing 10\%-19\% of the Daily Value per reference amount) include sweet potatoes, tomatoes and tomato products (e.g., tomato paste, tomato sauce, salsa, etc.), beet greens, white potatoes, white beans, lima beans, cooked greens, carrot juice, and prune juice (Centers for Disease Control and Prevention, 2012).

Follow these tips to add more fruit and vegetables to your diet:

- Keep a bowl of fruit on your dining room or kitchen table.

- Top your yogurt or cereal in the morning with fruit such as blueberries, strawberries, or raisins.

- Pack baby carrots, grapes, or strawberries for lunch instead of potato chips.

- Top your salads with fruits or vegetables (or both) for an easy side dish at lunch or dinner.

- Add extra chopped vegetables to pasta sauce, lasagna, pizza, soups, macaroni and cheese, or stews.

- When cooking vegetables for dinner, save and refrigerate some leftovers, and use within 2-3 days for an easy side dish another night.

- Take bananas, apples, or oranges for a quick and healthy snack at any time of the day.

- Have a fruit salad, baked apple, or a frozen juice bar (100\% juice) for dessert.

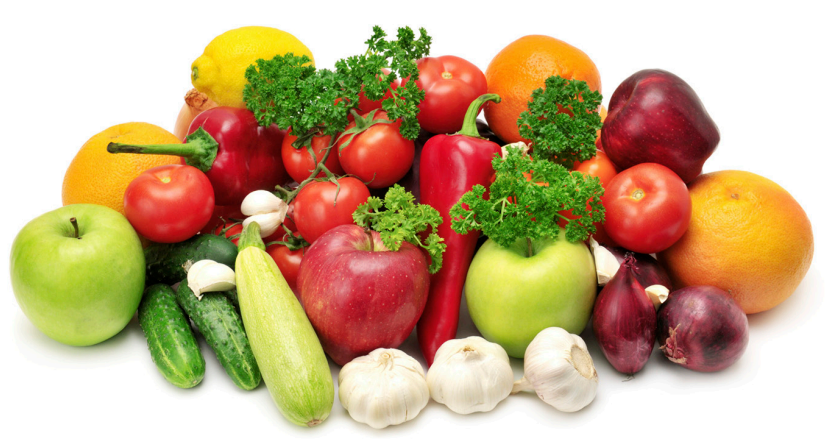

Figure 4. Fruits and vegetables are an important part of a healthy diet, and they can even help reduce risk for diseases and other health conditions. Credits: iStockphoto 


\section{Fruits and Vegetables Matter}

Fruits and vegetables should be a main component of every meal. They are low in calories and provide a number of vitamins that you need in your diet. By making half of your plate fruits and vegetables at every meal, you will reduce your risk for chronic diseases and may even protect yourself against certain types of cancer. For more information about fruits and vegetables, see the EDIS publication FY1196/ FCS8926 - Fruits and Vegetables at http://edis.ifas.ufl.edu/ fy1196.

\section{Recommended Websites}

USDA's MyPlate (http://www.choosemyplate.gov/): This site contains information regarding USDA's MyPlate and information about all of the food groups.

USDA Dietary Guidelines for Americans, 2010 (http://www. cnpp.usda.gov/Publications/DietaryGuidelines/2010/PolicyDoc/PolicyDoc.pdf): This document contains evidencebased information and nutrition recommendations.

Fruits and Veggies More Matters (http://www.fruitsandveggiesmorematters.org/): This site provides general information about fruits and vegetables, including cooking and shopping tips, and how to get your kids involved.

\section{References}

Anderson, J. W., Baird, P., Davis Jr., R. H., Ferreri, S., Knudtson, M., Koraym, A., Waters, V., \& Williams, C. L. (2009). Health benefits of dietary fiber. Nutrition Reviews 67(4), 188-205. doi:10.1111/j.1753-4887.2009.00189.x

Centers for Disease Control and Prevention. (2012). Fruit and veggies matter: Fruit \& vegetable benefits. Retrieved from http://www.fruitsandveggiesmatter.gov/benefits/ nutrient_guide.html

John, J. H., Ziebland, S., Yudkin, P., Roe, L. S., \& Neil, H. A. W. for the Oxford Fruit and Vegetable Study Group. (2002). Effects of fruit and vegetable consumption on plasma antioxidant concentrations and blood pressure: A randomised controlled trial. The Lancet 359(9322), 1969-1974.

Liu, R. H. (2003). Health benefits of fruit and vegetables are from additive and synergistic combinations of phytochemicals. Am J of Clin Nutr. 78(suppl), 517S-20S.

U.S. Department of Agriculture (USDA). (2012). ChooseMyPlate.gov website. Retrieved from http://www. choosemyplate.gov/index.html
USDA. (2011a). How much fruit is needed daily? ChooseMyPlate.gov website. Retrieved from http://www. choosemyplate.gov/food-groups/fruits_amount_table.html

USDA. (2011b). How many vegetables are needed daily or weekly? ChooseMyPlate.gov website. Retrieved from http:// www.choosemyplate.gov/food-groups/vegetables_amount_ table.html

USDA and U.S. Department of Health and Human Services. (2010). Dietary guidelines for Americans, 2010. 7th edition. Washington, DC: U.S. Government Printing Office. Retrieved from http://health.gov/dietaryguidelines/ dga2010/dietaryguidelines2010.pdf 